\title{
[W.P.S.J. の紹介]
}

\section{家离のコクシジウム症と 抗コクシジウム剂の取扱いについて}

A.C. Cuckler and D.F. Green: World's Poultry Sci. J., 23, 237-246, 1967.

（第 13 回万国家璃学会溝演：抄録同学会報， p. 452， 1966, Aug. 15-21, キェフ)

コクシジウム原出が寄生性を獲得してふら-な゙に久し い。コクシジウムが同一種から分岐し, 次いだ高度の宿

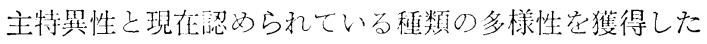
かビうかは，おそらく解明されることはないだろう。コ クシジウムは多数の哺乳類とトリ類の寄生虫として認め られてきた（DAviES ら 1963）。

多くのコクシジウムの分有は広いが，この顕微鏡学的 寄生虫に関する五々の知践は近年になって得られたもの なので，遺骸定残さないこの生物の進化上の变遷と分布 の様相定追求するのは不可能である。鵎は旧世界のトリ でアイメリヤ属の 9 種類が笴生しているとゆう記載は興 味ふかい。これにくらべて，七面鳥は新世界で発見さ れ，７種のアイメリヤ属コクシジウムの宿主となってい る。本寄生虫の一般形態はオーシストの段階でよく似て いるので，ある種類のものを他から見分けるには行届い た手技が必要であるし，生活環も酷似している。

繁殖能力: コクシジウムはオーシスト期には宿主に自 ら侵入する移動手段洼持っていず, 寄生宿主の攝取に全 面的に依存している。多くの寄生虫と同じく，橥偊維持 のため汸り知机ない繁殖能力炎持つ。この能力につい ては他の動物に打汀るりも䳕で, 定量的に研究されて きた。 8 個のスポロゾイトを包含与る 1 個のオーシスト 注数 10 万個の子孫它産生する。

鷄に関係卞るアイメリヤ属注隺主体内でシゾゴニー期 (無性的多数分裂過程) 2 回壱過し, それから有性生殖に よりチゴート（受精体）ないしオーシストを形成し，新 しく形成されたオーシストは粪中に排泄される。往っ て，1 羽のトリは何百万個もの源となる。㢣殖能力はコ クシジウムの種類により著しく買なり，E. maxima で 法最も少なく，うまく行って接種才ーシスト 1 個当り平 均 1 万侗程度であるが，E. brunetti は接種オーシスト

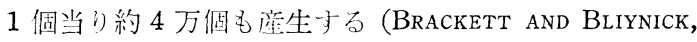
1949)。

コクシジウム症の臨床：人朋がトリ省禽化し，また そ机在食品として商業的に生座寸るようになったため, コクシジウムは種属の維持が保証さ机同时に宿主たるト リには危険な状態がつくられるに至った。
過去 10 年間に，この研究空で少くも半ば定星的と考 えられる計算法学用いて数干例の敷料を調心゙た。敷料 $1 \mathrm{~g}$ 当りにオーシストが 5 万から数 10 万個委で梌出される のが普通である。家禽は地面で採食し，本能的に敷料点 引搔いたり，ついばんだり导るので，トリ類がごえなに 飼育舎環境のコクシジウムに暴露されている少理解する のは容易である。

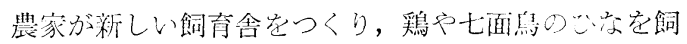
い始めることができるかもしれ就いが，結局コクシジウ ムが機械的な方法で鵎舍に持方込亦れ，その構内には1 ないし数種のコクシジウムが忍めら机る様になることが 米国では経験された。これらのトリがある程度の抵抗力 を示す様になるまでは，感染にさらされるとトリ机衰弱 ᄂ, 死收。

鵎で法 E. tenella と E. necatrix が 2 大病原性種で あり, 七面鳥では E. adenoides, E. gallopavonis, E. meleagrimitis がより重度の疾病原因となる。その他の 種類のコクシジウムでは整死損失は非常に低いのに，そ のうち数種のものでは食欲減退し, 飼料効率が悪化し, 飼育者に経済的な損失を与える様な病気をひき起しう る。

抵抗力ないし免疫：多数の研究により, 宿主には各種 コクシジウムに対し高度の抵抗力ないし免疫の発現のあ ることが知られている。抵抗力はコクシジウムの種類に 対し特異性がある。いく種類かのコクシジウムが単独の 宿主に寄生するので，コクシジウム症は一連の疾病群と して考えられ敉ばならない。例えば，あるトリの群には 明らかに病気が認められ、コクシジウム症と彰断される かもしれない。1〜2週内に，それらのトリは優勢な種類 のコクシジウムに対して強い抵抗力安あらわすだろう。

しかし, 他の種類は, 続いて别のコクシジウム症発生の 原因となり得る。この継発は腸コクシジウムについてよ く観察さ机ている。何年も前には, 慢性コクシジウム症 と診断するのはごくありふれたことであった。しふし， 異なった種類のコクシジウムによる急性の発病が継発すす ることがあるので，この様な診断法䛊っこいる。また， トリ類は普通 1 種以上のコクシジウム䘮保虫しているの だ，その感染定直もに特定種のコクシジウムによるもの と断定するのは容易なものでない（GREEN 5，1964）。 近年ある著明な寄生虫学者は, 腸管組織深部心侯入一 るコクシジウムは永続性免疫をつくり, 一方, 上皮細胞 にのみ寄生するコクシジウムでは，くり返してトリが感 染与る每に一眭的に再活性化さ机るに違いない不安定な 抵抗力が生ずる傾向があること冠証明した（HORTON- 
Sмiтн, 1962, 63)。

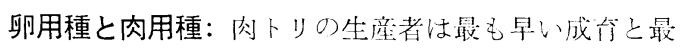
高の飤料效率に閶心を持つが，生産に当っては，対コク

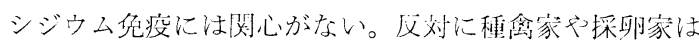
初産後にはコクシジウムの被尃をさけることに深い関心 を等せる。そ故，極力ニワトリをコクシジウムに暴ら さないように古るが，逆に䐴疫を与允ようとして曝らし すぎると汹う極端ふら極端を走りながら，若入スを成熟 させる羽目になる。産卵中のトリはひなの10偣も2 0 倍

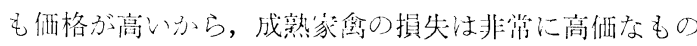
になる。

管理法：抗コクシジウム剂の阙発前は, 栓䳕象は敷料 の乾燥々心，湿った部分をとり除き乾いた擞料に才き替 えるとふ，水槽を窝㭙清潔に保つなどの赫生措哭にたよ

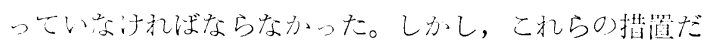
けでは不老分であって、コクシジウム症は多数の群に発

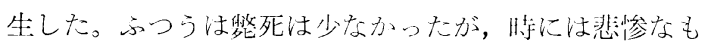
のであった（FosteR, 1949; SibALIC, 1957)。

抗コクシジウム剂の役割：面に有効な最初の抗二 クシジウム剂はサルフォグナニジンであった。LEVENE

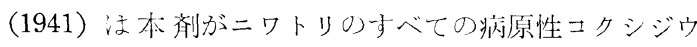
ムに有効なことを証明した。溶解性が恶いので，飼料 に混じてだけ投与された。次いで，サルファメサジン (Horton-Smith AND TAYLOR, 1942), さらにサルフォキ ノキサリン (Peterson, 1948) はコタシジウムの制厓上 さらに有効なことが放やった。

これら薬剤は最もひどくコクシジウム症に雃ったトリ 意救うこ上法出来ないが，当を得た治療を行なえば，二 クシジウムの発生と㟝断された後 $2 \cdot 3$ 日以内にその群の 秋死菜激減させることは研究者の一致した兄解であ る。与存わ古，火事だとわかるまでは待機しており，そ れとわふったら消そうとする消防のきり打に似ている。

予防法汾探索されたのは当然のことで，一連の研究か ら, 米国の研究者 (Delaplane ら, 1947; Grumbles ら, 1948）により，サルフォキノキリリン $0.0125 \%$ 投手に より，本病発生の抢それが最小限度に抑えられることが わふらな。さらに研究は 1948 年後半に䦌始され，間も

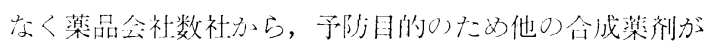
提供された。

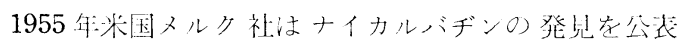

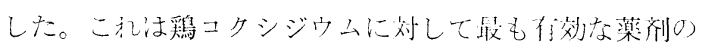

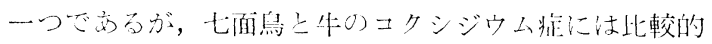
効果の登、ことがこ机束でに知られてきた（CUCKLERら， 1955)。

大多数の抗コクシジウム剂计符 2 期シゾントの発行に

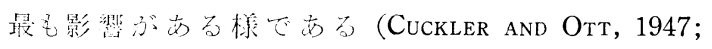

Horton-Smith and Long, 1961; Warren and Ball, 1963)。もしコクシジウムが長い阔ガメトゴニー（有

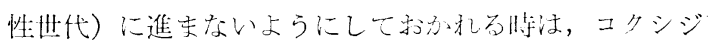
ウムは死えでしまうらしい。宿主の損傷は最少になり， 色疫機構が働き始める。

ブロイラーのために注，出来るだけ完全にコクシジウ

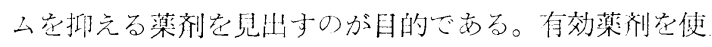
えば、コクシジウムの生活環の進行方抑止されるだけで はなく,トリがひどい感染に遇遇しても, 成唇, 姛料効 率も正管になる。整った生産条俳下では, 効果的な抗二 クシジウム剂の添扣によって，1～3％注ブロイラーの仕 上りがよくなるだろう。

ブロイラ一業者は上記の非渻に有效な薬剂至喜えでい る。一方, 更新用若入スの款成業者はコクシジウムの生

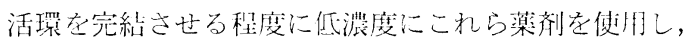
その絬果として, 满足な免疫の発現老促進与るに足る才 ーシストが用㜀に估在するようにしなければならない。

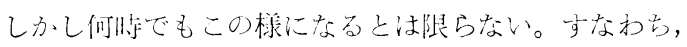
米国婻部渚州の片究者は 6 種のコクシジウムで测主した

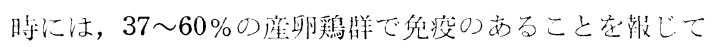
いる (REID AND KEENER, 1962)。

抗コクシジウム剂に対する感受性のコクシジウムの種. 類による変動：堽想的な薬剂があるとするなら, すべて の種耀のコクシジウムに刘して, 间一濃度で効果がある

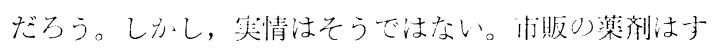
ベて同程度の效果在小持わけではない(MCLOUGHLIN AND Chester，1959)。束た、コクシジウム注に適応能力の すぐれた生物であることが経糇されている。選扒症いし

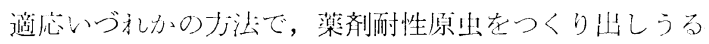
(Joyner, 1957; McLoughlin and Gardiner, 1962; Vegh, 1962)。

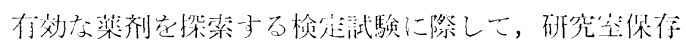

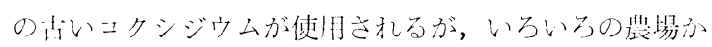
ら採取した $2 \cdot 30$ コタシジウムには, 鼠早やこ机ら保存 コタシジム程O) 莯剂感受性はない(CUCKLER AND Malanga, 1955; Pellerdy, 1963)。そこである葙剂の效

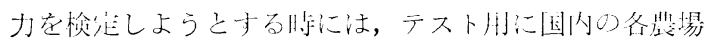
から新しく分離されたニ少シジウム集另努力が払わ

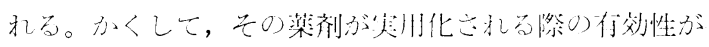
保証されるのである。

サルファキノキカリンとエトパベートに国少る最近の

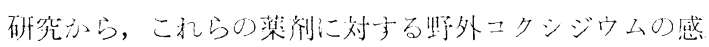
受性に法著しい变動があることがお小った。両種薬剂り

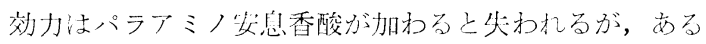
コクシジウムでは，一方の薬戍に非瑺に感受性があり，

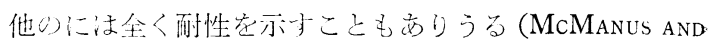




\section{CuCKler, 1965)。}

要約 鶏と七面鳥に打沙一連の疾病群としてのコク シジウム症の性格がのべられた。ニクシジウムのおどろ くベき繁殖能力注家の屋内飼育と結びついて, 疾病を 招来する。管理要因の改善だけではコクシジウム症を充 分䂆防することはできない。トリ類は各種コクシジウム に対し, 抵抗力京いし免疫獲得の能力老有与。抗士クシ ジウム剂はコクシジウムによる損吉を最小限にし，飼育 者䏠より效率的に家愈在生産与るのに役立っている。抗 コクシジウム剂の効力がすい゙て同一とは限らないし，各 種ニクシジウムに等しく有効とも限らない。薬郕耐性は 研究室条件下で毛起りうるし，同様なこと泩野外でもお こる。

(俈藤 儀平)

\section{鵎の選抜結果のもつ意味}

G.A. Clayton: World's Poultry Sci. J., 24, 37, 1968.

動物奇種学り理諭は，メンデル遺伀学かが自然に枝分れ したものであり，てれ汢今世紀初頭に発展した生物統計 学上開連の市子妇のでる。成長・泌乳量・多産性のよ う量的形質の改良に関古研究においては，郝間・

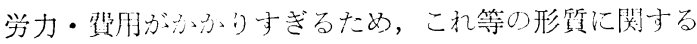

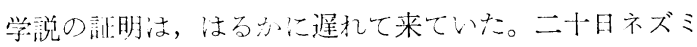
ベショウジョウ蠅のような实験動物を用いた若千の報告

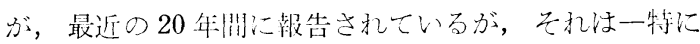

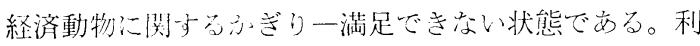

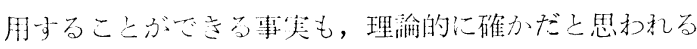

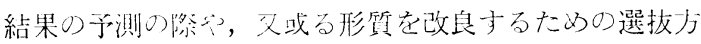
法の比較を行う聄公に法まだ不充分である。電子計算機 によるシミュレーション研究の場合，動物（又值物） の洒值や経済性は多ふれ少か机彼等が証明しようとして

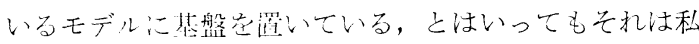

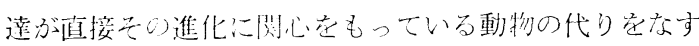
と汸みな得な。

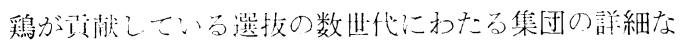

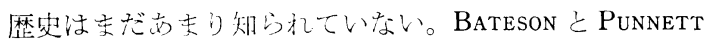

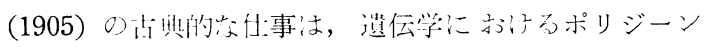

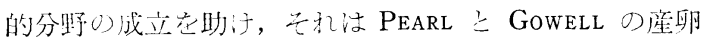
に閉する汜抜实駼によった引継が机た（LERNER 1948）。

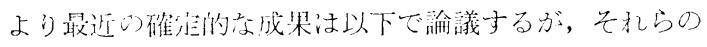
研究は他の動物の改良のため, あるい潐化衣深く理解

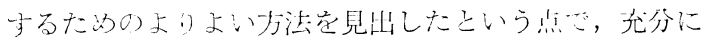

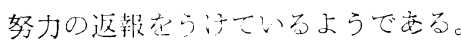

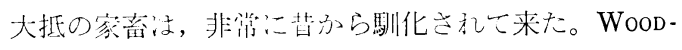

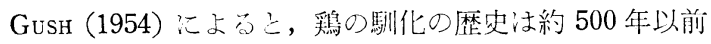
にさふのぼることがだきる，そしてDARWIN (1896) の鵎
の野生型が馿化された鵎に近いという指摘と考え合せる と，制化はもっと早期であったろらと考元られる。人颣 が選抜によって，鵎をどの位又どの様に効果的に変えて いったかということを，歴史から明かにすることは非常 に難しい。そしてこの事は重要である，何故なら，出発 点に関する知践なしに数多くの選报方法汸どのように効 果的に行われてきたかといらことを判断できないからで ある。

WOOD-GusH によると，現代の鶏と較べて棌色のない ほどの産卵能力它持った古代ローマ時代の采統があると いうことである。もしそうだとすると，それ以来 2000 年間における種䳕業者の無能力さの悲しきあらわれであ り，又より重要な量的形質の能力改良の際に障鼓がある であろうという警告でもある。 LERNER によって引用さ れている後者の歴史的記録によれば，それら系統のうち のあるものの産卵能力は現代の標準にてらしても良いこ とを示している。者の記録にはあまり信頼を标けない が，内輪に見程ってみても 100 年前のある産卵采の記録 は現代のそれにあまりおとっていない。

疑もなく，過去 30 年間の産卵全国平均法一特に米国 と英国に沶いて一明らかな增加定示した。そしてこの改 良治能力の覀い鷄群の広沉にわたる淘汰にかてて加え て, 疾病対策, 栄扂, 管理に関する知職の安質的な改良 によるものであることは留うまでもない。

米国，英国㧍よびヨーロッパ大陸における産卵鷄の系 統の大部分は，少数一約 6 つ一一寺種埸から供給されて いる，そしてこれら采統のあるものの腈では其通の起源 を持つ可能性寸らある，世界的な分们にして灌くべき 遺伝的基盤の也まさといえよう。今日普及されている， いくつかの主要な産卵系統に拈いて今世紀にどの位遺伝 的改良が行わ机たか，また我々は進歩を綐けているのだ ろらかというに大きな疑問に対する解答はなだない。

Hutr (1949) 注未選抜の野鷄と野鷄より座卵能力に出 いてはるかに優れている白色レグホン安較べ報告してい る。朋いた小羽数の野舀の記源と近交係数については述 ベていないので，未選扳の野舀の産卵の潜在能力を明確 に与るために法，もっと大規模な埤験が必要である。こ のことは，馴化の歴史をもたない野鳥の品種のあるるの に驚くほど多産のものがあるという事実からも強調され ね妓ならぬ。例えば, Howes (1965) は American BobWhite ウズラは年産卵が 250 老こえる能力があることを 見つけ，MARSHALL (1936) は, 野生の或亏品種で海日

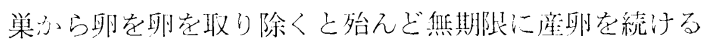
という事实䘮報告ししている。例としては，約150日间 の䌘殖シーズンで家隹は50 ケ程度, Argentinian Cowbird は 100 卵程度産毛ことが知号れている。 
選抜実験と育種理論を関係させようとした最初の実験 は, 1931 年にカリホルニア大学で行われた。LERNER (1950：1958) 汇この実験の汇まりりについて, 詳しく説 明し，そして去た世紀に入って以来米国で行われた産 卵能力に対与る初期の選扳実験の概史を考究している。

カリホルニア大学の実験は, 生存䳕産卵数でなく, 入 舎羽数平均を最初に用いたという点で重要である。入舎 羽数平均は鶏舎に飼われた鵎の羽数によって決るので斃 死率㛈慮されている，一方生存舀産卵数法特に整死率 の高い場合，家系の産卵能力艺著しく過大評価するであ ろう。雌鶏の選扳は 1950 年迄注全年記錄に, そ玑以降 は約 300 日歯市での部分記録に基ずいて行なわれ，この 形質の著しい改良が多られた。（図 1）それは約455日 歯迄の生存鷄産卵数とは必ずしも適合しないが，その点 についいは以下に論議される GowE らの結果が多分䚞解 きの手がかりを与えるであるう。(図 2〜4)

不幸にもカリホルニア大学の資料に扮いては, 憋死率 が $9.5 \sim 36 \%$ 平均 $19 \%$ と高かったため， 入舎羽数平均 は㭙期を比較する場合には役に立たなかった，図１にし めしたように入舎羽数平均法生存鵎産卵数より非常に低 い值として現われている。大体の推定の方法としては， 産卵鷄舎内での整死率が $1 \%$ 增えるごとに生存䳕平均の 産卵数は 1 ケ增える。カリホルニア大学舀群の入舎平均 産卵数の実際の增加は最初の 12 年間は年当り約 5.6 ケ で，実行された選抜強度とよく一致したが，それ以降に 打ける選抜反応㵔しく低下し実際には 1/6 程度になっ た。

この実験の初期の反応は選拔方法の効率に直接影響さ れなかったと考えられる根拠がある。まず第一に, 鶏群 注実験開始後 9 年間外部の血液から隔離され, 実験の初 期に導入された 3 羽の雄が遺伝的に大きな貢献をした。 この実験は選抜計画の明確なものとはいえず，むしろ HuTT (1949) に引用さ机ている初期に改良形質に急速な 進歩があったという LIPPINCOTT による貴化法により似 やよっている。

1930 年の水準からみても, この実験の出発時の能力は 低かったので，優秀な采統からの遗伝子の導入は，この 実験の最初の 5 年に多られたよらなすばらしい效果を示 すものと期待される。HUTT は DRYDEN とLIPPINCOTT を 引用しカリホルニア大学の実験以前および同時代に産卵 能力の高い系統が存在したことを示しながら, 1912 年頃 の生存鵎産卵数は 200-240 卵程度であろうと推定して いる。第 2 図の Gowe らの資料は対照群の入舎羽数平均 にみら机る增加一多分環㑽的なものであららが一を示し ている，これ法長期间の環境の傾向を割引いてはならぬ という警告と考えるべきであるう。
反応の速度はゆっくりであるとは心充，ABPLANALP ら（1964）によって推定された 1963 年こ $31 \%$ というよ うな近交係数の増加によっていくらふ访げら机て来たで

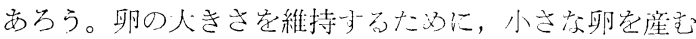
鶏は淘汰されて来たが，この実駼の目的法市埸に受け入

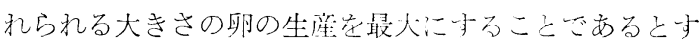
れば, 卵の大きさ注合的形質である入舍羽数平均の一 部分とみなされなければならない。この実駼から得られ た一般的な結論性次のようである，即ちもしそれを企然 やめてしまわないとすると産卵鷄舎に飼わ机た鷄一羽当 り 200〜210 卵辺りで進歩速度は著しく扮そくなってし まう。以下に論議される絬果の大半に少いて産卵能力は 500 日齢まで调查されたのに，この実験においては約 455 日画令までの調查であったが，もっとも寛大な解釈を したとしても，乙の系統の経済能力注一般に用いられる 商業品種に比較すると普通である。

カリホルニア大学の初期の報告 (LERNER 1950) のよ うな楽観的な考方方は，後の実験結果によって今や弱为 られて来ている。産卵鵎において, 数多くの形質学選抜 しようとして失敗した DICKERSON（1955）の仕事は，そ の種の最初のものである。DICKERSON 注経済形質を 30 年間選抜して来た系統について報告している。彼注形質 間の負の遺伝相関と, 遺伝と環境の相互作用といらこと で説明しようとした。彼は，大舎羽数平均産卵について は報告していないが，生存鵎平均産卵が 1931 年にとの 後 24 年間の最高である 231 に達したこいうことは注目 に值いする。

この最高能力の程度が, 沢山の文献に現われているる のと同様なのは意議深いことである。MORRIS (1963) は, 11 年問の選抜実験において，DICKERSONのそ秃よりはや や低い限界に達したこと，部分記録選抜による産卵初期 の增加は終期の蓙卵数の減少によって相殺されることを 示した。これは DICKERSONが心配していたことの一部の 裏付けといえる。以下で論議する, Gowe の結果は, も っとはっきりした事実を提示している。

動物育種理論, とりわ舀の改良に闺寻る最毛重要な 実験の 1 つが 1950 年にカナダで始められた (GowE et al 1959)。それはいくつかの場所にわたり大規模に行なわ れ，無作為な環境效果最小心乙，又経済動物学使って それを正しく統制した数少い実験の1つであるがため重 要である。GowE の実験には 2 つ大きな興沬の焦点が ある。そ机は刘照系統そ机自身の動きと, 選抜をう汇た 2 系統の対照からのはなれ具合である。選抜をうけた 2 系統の1つは, オッタワ対照䍵からの分枝であり, 他活 別の起源のものである。

オッタワ詨照群の初期の歴史は, GowE 等汇よって報 
告されている。その特徵は図 2 亿 4 に示さ秃ている。その ような選扳が止められた場合，選抜の歴史老もつ高能力 の采統がぞうなるかということは興味媣いことである。 例えば対照系統のような特别の場合は, 遺伝的安定性を 保つために，次の世代に各々親として残るというような 完全な緩和とは違っている。自然淘汰の力は弱めら机る であるらが，決してなくならない。

第 2 図恃第 1 図と比較されるべきである。オッタワ対 照系の全平均は, いづれの年もカリホルニア大学の場合 の 2-4 倍も多い約 1,300 羽の鶏から得られている。第 2 図の最も重要な特徵注, 座卵能力の低下が全然見られな いということである。この資料注産卵能力の実際の増加 をしめしたが, GowE はこ机は管理技術の改善による結 果と考元ている。

オッ夕ワ対照群の場合，入舍平均羽数は，200 卵程度 で, 生存鷄平均産卵数は約 225 卵であり, 産卵能力は力 リホルニア大学の鶏群とあまり違わなかった。最も明ら かな改良は, 産卵期間の上半期に㧍ける産卵増によるも ので，そ机は性成熟が早まったためと思われる。

オッタワ対照群の産卵成績からうける一般的印象か ら，産卵のもとになる経済成分の高い状態に刘して働く 自然鍌汰の力は無視しらる程度であることがわかる。こ の説明は能力が現在の程度のこの系統に対してだけ適当 と思われるが，閔連形質のより高い水準に沶いて，又他 系統に対しては状況は異るであるう。CLAYTONと ROBERTSON (1966) は, オッ夕ワの結果と大体一致して いる彼等自身及び他の研究結果它報告し, 改良を続けて いった場合の失敗を考慮に入れて適当に説明することか 段々難かしくなって来たことを示している。

現在我々の知識の不足は, 高能力系統からの逆選扳の 事実がないことに依っている。LAMOREUX 等 (1943)に よる, 能力の低い系統劣用いて 1913 年に出発した選抜

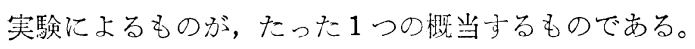
彼等は, 少々の困難があっただけで産卵数を減少させる ことができた。もし逆選抜が現代の系統を用いては有効 でないとすれば，我々は実現することのできる遗伝分散 がすでに消耗しきっていると結論せざるをえない。そし てそれから実際面及び理論上の困難を想像できる。確認 の必要はあろらが, 慣行の分析によると, そのような系 統に遗伝分散が見出されることを考慮するならば，この 結論はあまり見込がない。

オッタワ対照群と同时に2つの系統が卵重に若干の注 意を払われながら，産卵能力妾部分記録で選抜されてい る。各系統約 3000 羽の鵎が, 毎年, 4 場所に飼われた。 これら系統の初期の歴史については, GOWE 等の論文を 見て頂きたい。一緒に計算された資料に基づく選抜結果
は図 2〜4 に示さ机ている。図 2 注 500 口歯令なでの入舎 平均産卵数を示している。これら図の中で対照系統の值 は太線で示されている。乙れな乙には，声種家は容易に 永く引続いた進歩があったのだと確信してしまうだろ 引。

その絬果が, 対照からの编差として袁現されると, 話 は違って米る。選报の初期には䟚敏な反応がみられる が，それ浪すぐに頭打ちになってしまら。これ等采統の 最高能力が，230-240 卵の間にあるこ二汇注意世放代 ならぬ。これは以下で諭議される経済能力㭘定で得られ たものと同様である。

Gowe（1962-1963）は，2つの選抜さ和た系統と対照 系の生存鵎平均産畉数と整死染てついて報告している。 彼は生存鵎平均之入含羽数平均産卵之の閒の高い相関を

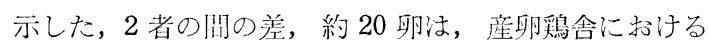
愁死率が 10-12\%の範囲であることから説明される。

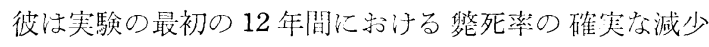
荙し，もし対照系統がないとすると，この改良㳘種 家にとって彼の努力の結果であると考えら机たであるう ことを示した。

選抜の本当の効果は，選抜された系統に方いて䌘死率 が 3-4\%に直ちに縮まりその後变化がなふったことに よるものと思われる。この評論の観点からい光ば, 整死 率は入舎平均産卵に対する制限因子の1つでないこと注 明らかである。もしそうだとすると，産卵数空增加させ る越抜が憋死率を減少させる，そしてこしから，自然淘 汰が産卵能力の高い鶏の生存率を減少させるということ 它通じて選抜反応定妨げることがないと判る。

図 3 は，産卵記録の前半と後半の間の傎の相関定示し た MORRIS (1963)の結果支支持卞るものでる。対照 系統は遺伝的に一定であるという仮定のもとに, GowE （1963） は産 卵期間の前半と後半との間に負の環境相関 が存することを示唆している。彼は対照系統に示された 確かな環境の傾向ばかりでなく, 対照系統より多い選抜 系統の産卵数に現われた部分記録による反応の存在も示 している。(図 3)

図 3 に示された負の遺伝相関は, 産卵期間の初期に現 われた 15一20 卵の産卵増加が, 後半に相殺されること を示している。初期の産卵增の大部分は, 選抜された系 統の性成熟がより早くなったためであることを示してい る。(図 4) 育種家にとってこの教訓は鶏の繁殖期間のよ り長い部分にわたって考慮せ补ばならぬということであ る，しかしこれは彼が全生産能力学改良することができ ることを必ずしも意味しない。性成熟が早まるという傾 向は，経済的に適当な鵎の生涯の長さ炎短縮し，ひいて は維持の費用を安くすることを意味する。 
図 3 と図 4 の比較注，力ナダの実験における卵数と卵 重との閒の負の関係写はっきり示している。卵数の增加 は明らかに，甽重が大きくなるように弱い選抜が行なわ れたのにも拘らず，即重の犠牲の上で獲得された。最後 の 3 年間で, 卵重に封与る選抜は值ぐに反応が現わ机て

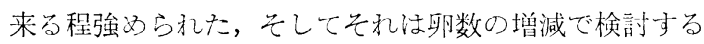
ことができる。(図 2,3)

カナダの実䮖流、いままで行なわれたものの中で最大 であること注忘礼られてはいけない。各系統とも4 場坼 に飼われた約 3,000 の個体からなっているので，得られ た傾向法本当に简頼に゙るものである。入舎羽数平均が 230 卵程度で頙打ちになるということは，産卵数が初産 日齿令や卵垂上負の相関定毛っていることで一部説明でき る。しかし尔がら，産卵能力が良くなることが生存率䘮 低下させ尔いということは心強いことである。

図 5 注 HALE こClayton（1965）の報告にさらに2 年 間の資料案加えたものである。主要点は，主な形質にお ける一層高以反応等得ようと8 年间にわたって選抜して 失敗したここだある，例えば産卵数の場合，いままで論 議されて来た他の記録にはるかに達しなかった。実際そ れは図 5 に示されているるらに卵数における反忘に負の 影響をもつであるう卵重の明らかな增加よりも非常に少 いものであった，全体としてはあまり希望のもてるもの ではない。

さて，1959-1965の7 年間にわたるアメリカ経済能力 検定について考光てみよら。数值恃每年発行される U. S.D.A.R.S.A. 出らとられている。この国の全土にわた り約 20 検定埸に行わ礼ている経済能力検定の大抵に関 している6っの種鶏場に注目してみた。

銘䢶ごとの鵎の数は，検定ごとに 50〜678 羽と異って いた。銘柄ご上の平均羽数注約 150 羽であるが，多くの 大種䳕場法特别の検定には 1 つ以上出品しているである う。しふしここだとりあげられた 6 種鶏場では年当り 最低 2,000 羽法下ら交心と思われる。これら一流 6 種鵎 埸からの出品鵎法，こ机等検定の多くに出品されている コ一ネル刘照群上比較された。大抵の检定は 500 日歯命ま で行なわ秃た，乙ふしこれと他の差は，個体検定の差の ような主要な影䇾孛考慮したあとに，さらに個体の総平 均に対与る回帰によって修正された。

図6以降示示礼る1963-1965の最後の3 年間の值 は，2年间をこみにした平均に基づいて計算された，こ 机治能力の年次によるるれを減少させているはづであ る。U.S.D.A. ○资料加ら注種鷄場が，一定の名前、出 品している慆群老全部あるいは一部かえたかどうか学確 かめることはごきない。大きな種鷄場の多くは 2 つ上 の違った采統空㟧品しているのでこの場合，最もよい
と思われ，出品羽数も最大の系統だけがここに記録され ている。

regressed mean の不利な点の1つは, もし全く同じ 能力をもった平均以上の 2 系統を比較した場合，出品羽 数の少い系統が明らかに不利になることである。能力が 平均以下の 2 系統の場合，出品羽数の少い方が平均に近 くなり，優利になる。ここで論議される比較の場合， 6 一流種鶏場の出品鷄之対照采統の全ては, 出品羽数 も多く，これ等の比較の際には Combined regression technique を脚ているため，大きなひずみは生じない と思われる。

図6には，経済的に最も重要な变量である入含平均産 甽数が描かれている。いくつかの重姴な特徵が現わ机て いる。その 1 つは，最後の6 年間に改良の父配が全然見 られないということである。刘照と比較すれば，6つ0種

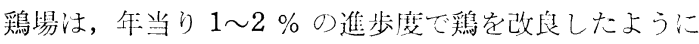
みえるが，対照系統の能力が懸るくなったという可能性 を捨てるわけにはいかない。KING 等 (1963) は Cornell でこの系統を研究し，1955年開始当初 6 年䦌の著しい安 定性について竍告している。

将父も管理の变化もおこらないのに何故対照系統が， 安定の 6 年間の後で变化したのかは，遗伝的に全く测明 できない。もし实際のところコーネル対照群が遺伝的に 变化しないことが示されたならば，全国にまたがる継綍 的な塄境の影響が，以下に述べられる頭打ちの原因に なっていることが示されるに違いない。このことは，刘 照系統の入舍平均産卵数が 6 系統の平均より低く，絾後 の3 年にいたっては，全平均より落ちているのに，後者

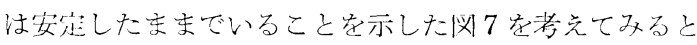
采当な院明とは思えない。全平均は各年に出品された全 群によって決定されるので，これの変化はある系統は出 品からはずれ他が新しく入って来るということによるも のである。

この検定の規模と, 参加者の大羽数を考えると, 構成 員の少々の变化が全平均に大きな变化を与えるとは考元 られない。コーネル対照群とは対称的に，6系統の平均 と全平均の揹の巠は，大体一定である。1965 年の成縜 は，その痓が維李って来つつ市ること学暗示している。 もし真の遺伝的な進歩がいくらかでもなされたと少れ

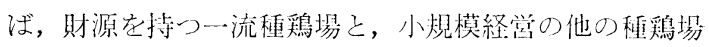
との差は開いて行くものと当然考えら机る。こ机に文し て働く唯一の因子汹少恶な采統の速かな淘汰であるう がこのことが行われたといら明宁な事実もない。

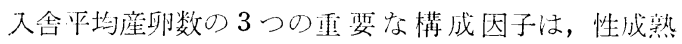
(図 8), 生存鵎産卵率 (図 9), 産卵舎での蒊死率 (図 10) であるが，6系統に比し対照区のそれは全て少っている 
ことがわかる。長期にわたる賁の環境の影響があり，一 方対照系統は遺伝的に一定であり, 全集団は遺伝的に進 歩したとするもう一つの仮説はより可能性が少いように 思われる。不幸にもこれらの資料はこの疑問を満足に解 くことができない。そして他の対照が疛い場合に, 相当 する種鵎場による改良を伴った仮定の負の環境の傾向を 取り除くことのみが，この第 2 の仮説の可能性を増すよ うに思われる。

6 図で注意せ补ばならぬ第 2 点は, 全ての-一流銘柄の 入舎平均産卵数が 225-240 卵のところで頭打ちになって いることである。これより高い能力の記録注存在はす る，しかし U.S.D.A.によって報告されている検定の上 ではこの記録を上まわるものはない。この産卵の程度は 鶏の能力の遺伝的な限界意味するものだろうかという 疑問がおこって来る，もしとうならば，他の対照となる 材料を導入して確める努力をすべきである。

図 6 と図 13 によって示されている, 第 3 の重要な点 は，6つの銘柄の間にはあまり差がないということであ る。これら種鶏場の大抵はできる丈科学の力に委ね, 育 種計画に力をつくし, 育種の異る方法を採用しているこ とが知ら机ている。即ちあるものを近交をし，最もよい 交雑を作る系統を選ぶ。相反反復選抜は系統間交雑に引 続き, 純系を選抜する。その他これらの変法等々であ る。どの方法も他にまさっていないことは, 図6から明 らかである。この状態は, 相加的遺伝分散が選抜に有用 な遺伝的变異の根本的な素因であった場合にだけ起って 来る，そしてこ机は複雑な形質の場合の超優性又は上位 性介在の可能性を弱めてしまうに違いない。

大抵の商業的に成功した鶏群が系統閆交雑であるとい う事実はこの論議の必要性を示している。近交退化を 除去することはさておき, 単に最後の複雑な生産形質だ けが測られたとしたら，それを構成している形質の相加 性が，雑種強勢とか超優性とかで説明されてしまうであ ろう。(Williams 1959)

図 11 に示される卵重の場合, コーネル 対照群は著し い安定性を示し, 变化をみせていない。このことは驚く ベきことで，もし対照系統によって示される他の形質に おける傾向が, 環境に支配されるとしたら，相関反応と して卵重の増加が見られると期待するのは当然だろら。 もしこれが起らなかったら, 対照系統が遺伝的に変った という可能性がでて来る。

この動きは, 図 3, 図4 にあるオッタワ選抜群及び図 11 にある $\mathrm{D}, \mathrm{F}$ と対比されるべきである。後者において は卵重は最大に達しているが，図6を見ると産卵数にお ける損失がわかる。オッタワの結果では, 卵重増のため に弱い選抜を行なったにも拘ず，この形質は卵数の増加
とともに低下し, 異常な結果と思われるコーネル鶏群の それと反対の動きをした。

入舎羽数平均の重要な組成をみてみると, 図 8 の性成 熟, 図 11 の卵重に於ては, 6 銘柄とも違っていない。 卵重についていえばこの説明は, 最後の数年間について のことであり，組成となっている形質の少くとも 1 つは 選抜によって急激に変化したことを示している。しかし ながら，銘柄間の遺伝的な差は，四 12 に示されたはっ きりした体重の差と，図 9 に示された生存鶏産卵率にお ける差とから推し測られるであろう。

体重が一番重い䎹統は, 最大の卯を生産し, 最高の産 卵率を維持するが，図 10 にあるように産卵鶏舎での整 死率が高いという欠点があるようである。これは，全て あるいは数多くの目的形質の改良を妨げるような負の相 関が組成形質間に存在するだろうという DICKERSON (1955) の予言の通りの例である。この負の相関がある 程度変えることができるという嬉ばしい例は， G 系であ る。G 系は図 12 に示しているように，維持のための飼 料要求量が低いという経済的利点である小さな成体重 と, 図 11 にあるような大きな卵重, 図 9 の高い産卵率を あわせもっている。この例外的な形質の組合せの結果 は, 図 13 に示されるように飼料費を差し引いた粗収益 で判断してみるとこの系統が常に優れていることを示し ている。

図 13 は，綮密にいえばその時のアメリカの状態にし か適応せず，卵質の評価基準や飼料の值段が变ればこの 順位も変るということを忘れてはならぬ。

$\mathrm{G}$ 系は複雑にまざり合った形質の能力を最大にするた めに, 反対の形質間の関係をある程変えることができる という心強い例である。

対照系統も別のよい例である，この場合それは大きな 体重と小さな卵重をもっている。全ての報告は, 系統内 において体重と卵重との間に高い正相関があることを示 してるにも拘ず，この関係は系統間では実際に変えるこ とができるのは明かである。

実業的な育種計画の最終の目的は経済効率にある。そ れは絶体的な正確さで決めることは難しいが飼料費を引 いた粗収入はたしかによい手引となる。この变量は非常 に相対的なものであり, 最も重要である消費者の要求や 飼料費等の外部要因によって大きく影響される。それで もなお，図 6 の入舎羽数平均産卵之図 13 の粗収入との 間には非常に密接な関係があることはすぐわかる。これ は育種家にとって重要である何故ならとれは産卵数だけ を重視して沈いけないといらことを強調しているから である。飼料費, 篗代をこえた収入に基づいている図 7 は, 1965 年までの 7 年間の一般的傾向を示している。優 
良銘柄系統は，全山品鷄售に比し，その位置を少し改善 したが，単一組成形質で判るまでに改善されたものはな

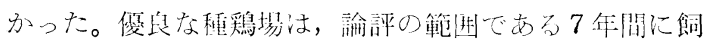
料と雛代を差し引いた收益で $24 \%$ の減少をこう导った が，対照采統では1959年を基準にして 48\%の減少在示 した。

全群の遗㑂的な平均が低下したし信ずる根拠は全くな

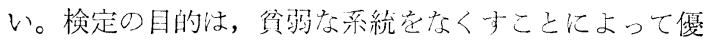
秀な采統をふやすをことにある。全体の遗伝平均に全く变

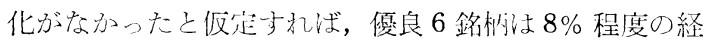
済効率の改良が行わ机たが，仮傮なく推部合する刘照系 統は16\%も低下した。もう1つの仅説は次の通りであ る，即ち，対照系は遺伝的に安定であり，ために6 銘柄 の経済効率は信じられないほど高い $24 \%$ の遺伝的改良 が行われたと信ずることである，実際とれ注ど見事な改 良の割合は，世界中で匹敵するものはない。

AbPlanAlP (1962) は, カリホルニア大学䳕群は例え ば卵重を考えない部分座卵記録のような組成形質は動か すことはできたけれども, 全体の能力が頭打ちになった のだと考えている。他の事実は MORRIS (1963) と同様で あるが,この可能性のもっと深い分析はDICKERSON (1955)

の Genetic Slippage に関古る論文である。

DICKERSON は商業品種に於ていくつかの経済形質につ いて 30 年間にわたって選抜した結果を報告している， 実際的に組成形質の全てにまだ遺伝的変異性が残ってい るにも拘わらず，この鶏群が限界に達したと結論せざる を得なかった。DICKERSON の場合，504日间の生你鵎平 均最高值は約 230 卵でこれはその後 20 年間の選抜でも 越されることはなかった。

\section{結論と要約}

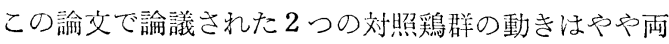
立しえないものであった。オッタワ対照系統に於ては, 調べられたいかなる形質にも退行はなかった。しかしな がらユーネル対照系統に於ては出発後 5〜6 年後から, 能 力低下がみられた。後者の場合, 変化はそれほど著しく なかったがもしそれが遺伝的だとすると他の鵎群におけ る進歩と評価する場合，ひどい間違いを抢かすことにな りか称ない。オッタワ対照舀群の安定性及びェジンバラ

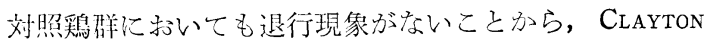
と RoBETSON (1965) は, 緩和された系統に退行がタられ なかったという報告を引用しながら、コーネル詨照群は 遗伝的に变化したと考える方が妥当であるとした。立派 な実験結果なしの空論壮無用である。

経済能力検定の結果から, 異った種鵎場からの鵎群の 能力は大体同じ程度に涬した。全体的な経済的長所ばか

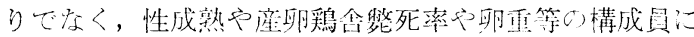

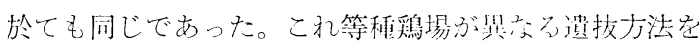
行なつているという事実にかんか子，経济的应座卵能力

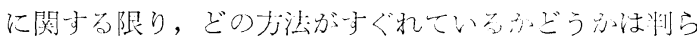
ない。势種家にとって，このことは，簡㧘こ安い育種力 泣がより众入りな方法と同じように能力の維持有効で あること意味している。遗伝学者に上ってはこれれ

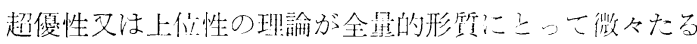
ものでありより簡単な相加的模型が有効であること变

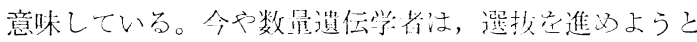

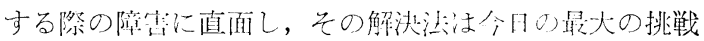
である。

注：四は World's Poultry Sci. J. 24, 41, 1968. 在 参照して下さい。 (小宮山 鉄朗)

\section{日本ウズラの断嘴}

S. Mahn and R.L. Blackwell World's Poultry Sci.

\section{J., 2458 (1968)}

性成熟後に日本ウズラを交配すると，で゙くつつき合 うことが多く，産卵が低下したり，死亡したりする。溃 伝的に選抜された個体の場合は被害が大きい。これに対 する対策して，性成熟に達する前から交配したり，交配 するときに断嘴する方法がある。ここでは，断嘴の効果 について検討した。

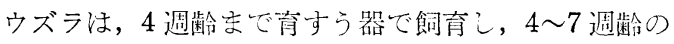
期間は，6×6×6 インチのケージで単飼した。9 94 羽を與 作為に組合せ，23組它対照区とし，24 組在断嘴区とし， 断嘴は普通の爪切りを用いて交配時に実施した。交配 3 日後から種卵を採取してら化し，雊は各群から30羽引゙ つを育成して，4週齢時の体重を測定した。

59 日間の産卵数泩, 断嘴区と対照区で, 1 組あたりそ れぞれ 30.25 コと 27.65 コで，差は統計的に有意とはい えなかった。断嘴区で䧳 3 羽, 雄 1 羽が死亡したが，こ れはつつかれたためではなかった。これに対し, 対照区 では, 此 4 羽, 雄 4 羽が死亡し, そのうちの雄 1 羽, 䧳 2 羽は,つつかれたためであった。ふ化率は, 断嘴区 $57 \%$ ，対照区 $39 \%$ で，その差は有意であった。

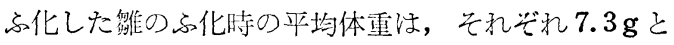
$7.4 \mathrm{~g}$ であって, 4 週齿时の体重は，それぞれ $82.8 \mathrm{~g}$ と $86.1 \mathrm{~g}$ であった。

この実験において実施した程度の断嘴では，回復が速 くて, 2 週間後には対照区と区別がつかなくなっている。 したがって，この方法は，交配直後の斗争を緩和する上 で有効で, それにより, ふ化率が上昇し, 死亡率が低下 するものといえる。

（吉田実） 